sandstones are interpreted to be calcareous turbidite deposits (see Horton and Schmitt, 1996). Overall, the assemblage of ungraded and graded matrix- and clast-supported conglomerates, interbedded with horizontally stratified sandstones and granule conglomerates and massive sandstones and mudstones, represents deposition in a subaqueous or subaerial fan-delta system, formed when an alluvial fan meets a standing body of water (see Nemec and Steel, 1988). Deposition was dominated by subaqueous debris-flows, interbedded turbidites, wave-influenced, shallow water sediments, and hemipelagic deposits (see Horton and Schmitt, 1996).

\section{Structural Interpretation}

We interpret these strata to be a conglomerate and sandstone intrasalt inclusion (Fig. 11). An intrasalt inclusion, also called a stringer, is a non-evaporite, more competent lithology originally deposited within the layered evaporite sequence, which was subsequently broken up and deformed within the salt during salt wall growth (e.g., Strozyk et al., 2012; Jackson et al., 2014). Salt inclusions can reveal information about depositional environments during the time of evaporite deposition and the internal dynamics of the salt diapir (e.g. Jackson et al., 2014; Alsop et al., 2016; Hudson et al., 2017) as well as the regional sediment routing during salt deposition (Fig. 16; also see below discussion).

\section{EVOLUTION OF THE SINBAD VALLEY SALT WALL}

Proximal to the Uncompahgre Uplift, a prograding sediment wedge of the upper Pennsylvanian Honaker Trail Formation through the Permian Cutler Group drove lateral salt withdrawal and initiated diapirism in the northeastern part of the basin (Trudgill, 2011; Figs. 17, S1, S2 [footnote 1]). However, the Honaker Trail and lower Cutler strata are conformable and do not show significant growth, thus passive diapirism had not yet initiated. The Sinbad Valley salt wall, given its proximity to the Uncompahgre Uplift, initiated during the late Pennsylvanian. At this point along the Uncompahgre Uplift, the Honaker

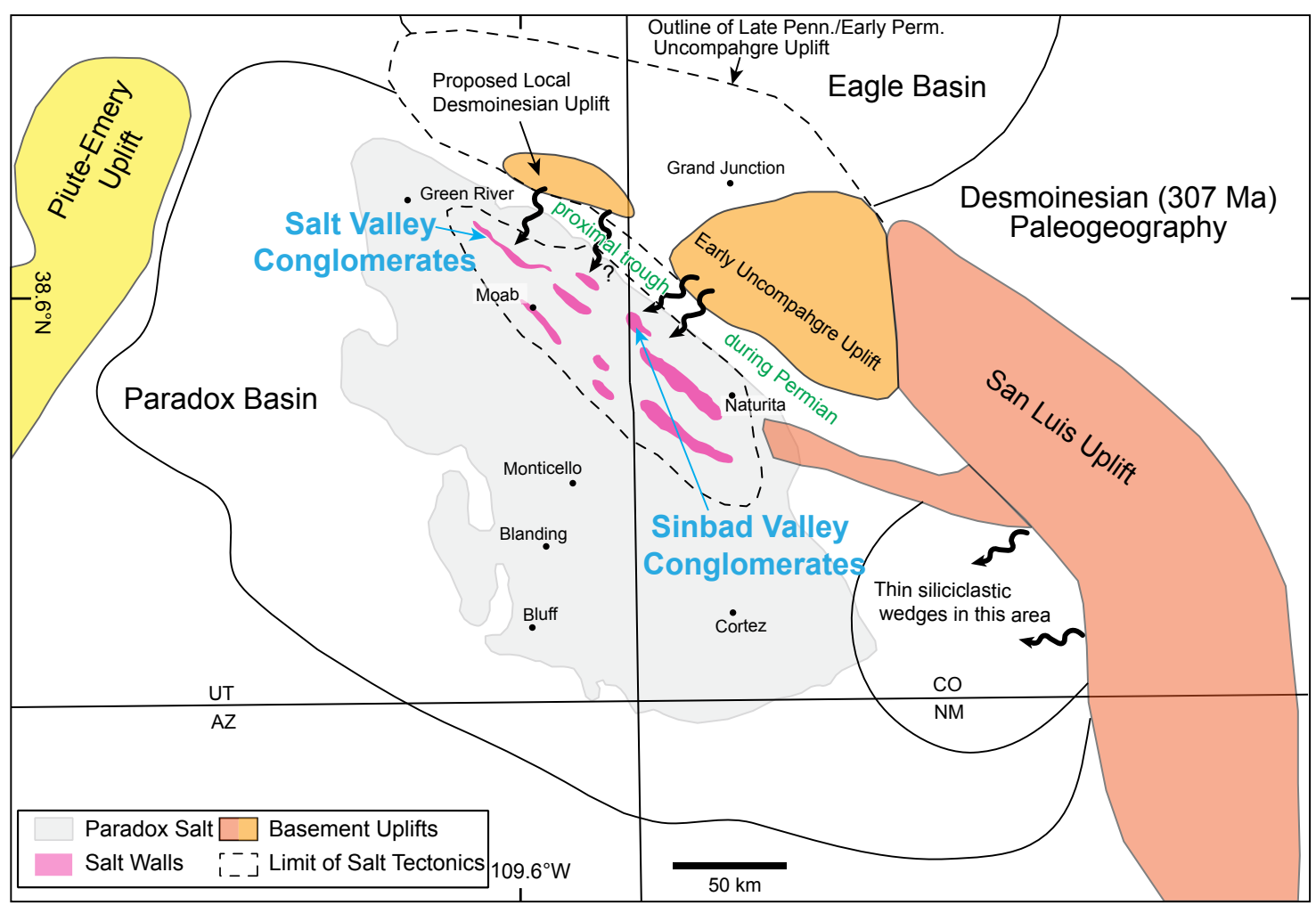

Figure 16. Desmoinesian paleogeography llustrating proposed source area for Sin Figure modified after Ra, conglomerates. Penn. Pennsylvania; Perm - Permian; UT - Utah; CO-Coriar NM-New Mexico. To view Figure $16^{\prime}$ “' "Is" layer in the PDF version of this paper, bels Ren full-text version of the paple reading the doi.org/10.1130/GESO2089.16 to of the figure.

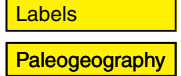

